\author{
Anne Håland \\ Universitetet i Stavanger
}

DOI: http://dx.doi.org/10.5617/adno.4820

\title{
Hvordan samtaler lærer og elever om modelltekster? Et bidrag til modelltekstdidaktikken
}

\section{Sammendrag}

Bruken av modelltekster er sterkt vektlagt i norske lcereplaner, men det meste av didaktikken er utviklet i Australia der tekstsamtalene som brukes, kjennetegnes $a v$ en streng form for samtale. Tekstsamtalene, ofte omtalt som dekonstruksjon av modelltekster, utgjør en viktig del av modelltekstdidaktikken. Denne studien undersøker hvordan en larer i norsk skole samtaler om tekster med utgangspunkt i modelltekster, og hvilke samtalemønstre som finnes i slike tekstsamtaler. Datamaterialet består av tekstsamtaler gjennomført på 5. trinn. Samtalene tar utgangspunkt i noen bestemte språklige trekk som elevene kan prøve ut i etterkant av tekstsamtalene. Samtalene er analysert med utgangspunkt i dialogiske samtaleteorier. Analysene viser innslag av dialogiske mønstre og disse mønstrene er knyttet til de utforskende delene av tekstsamtalene. Analyseresultatene gir grunn til å diskutere kvalitetstrekk ved modelltekstsamtaler. Artikkelen bidrar til modelltekstdidaktikken ved at den utarbeider spørsmål som har til hensikt å hjelpe elevene å oppdage, utforske og utfordre språklige mønstre.

Nøkkelord: modelltekster, dialogiske samtaleteorier, dekonstruksjon, modelltekstdidaktikk, samtaledidaktikk

\section{How a teacher and her students talk about model texts. A contribution to the model text didactics}

\begin{abstract}
The Norwegian curriculum puts emphasis on the use of model texts in education. Text talk, which is also referred to as deconstruction of model texts, is an important part of model text didactics. However, as this didactic method was developed in Australia, where the text discussions frequently are structured and teacher-led, it might not be adequate in a Norwegian context, where classroom communication commonly is looser. The study investigates how a Norwegian teacher talks about model texts, and which dialogue patterns that occur during these talks. The data material consists of text talks from a $5^{\text {th }}$ grade classroom (age 10). These talks include specific textual features that the pupils are
\end{abstract}


encouraged to explore when later constructing written texts on their own. The theoretical framework for the analysis of the data material rests mainly on dialogical theories. The results of the study indicate that dialogical patterns are at play during text talks and the dialogic patterns are more distinct in the exploring parts of the text talks. The results of the study provide a foundation for discussions about qualities of disciplinary talks about model texts. It is the hope that this article, by suggesting questions that might encourage pupils to discover, explore and challenge text features, will contribute to the field of research about model text didactics.

Keywords: model texts, dialogical talk theories, deconstruction, model text didactics, text talk didactics

\section{Introduksjon}

En modelltekst er en tekst som tydeliggjør språklige trekk som en ønsker at elevene skal eller kan bruke i egen skriving Bruk av modelltekster i undervisningen har fått en sentral plass i Kunnskapsløftet (Kunnskapsdepartementet, 2006), spesielt i norskfaget, og det finnes gode grunner til å arbeide med modelltekster i skolen. Studier har vist at elever bruker et sett av språklige mønstre fra tekster de har lest (Håland, 2013; Lancia, 1997). Men studier har også vist at modelltekster ikke gir nok skrivestøtte i seg selv (Hillocks, 1986), og at modelltekstene trenger å bli fulgt av annen type støtte, slik som lærers instruksjon og forklaring (Stolarek, 1994). I modelltekstdidaktikken er særlig tekstsamtaler, ofte omtalt som dekonstruksjon av modelltekster, framhevet som særlig viktig støtte (Callaghan \& Rothery, 1988; Cope \& Kalantzis, 1993; Rose \& Martin, 2013).

Modelltekstdidaktikken har sitt opphav i antikken, men fikk fornyet interesse i Australia på 1980-tallet. Den systematiske bruken av modelltekster er ikke like utbredt i Norden som i Australia, og det finnes lite forskning og didaktisk materiale som gir føringer for hvordan modelltekster kan brukes i klasserommet, bortsett fra noen oversettelser fra engelsk til svensk (Hedeboe \& Polias, 2008; Rose \& Martin, 2013). Hensikten med denne artikkelen er å undersøke spesifikke samtalemønstre når lærer og elever i en norsk skole samtaler om modelltekster, og på den måten gi et bidrag til utvalgte deler av modelltekstdidaktikken i en nordisk kontekst. Artikkelen henter sitt materiale fra en større kvalitativ kasusstudie som undersøkte bruken av modelltekster i skriveopplæringen på mellomtrinnet (Håland, 2013). Materialet består av klassesamtaler om modelltekster. Analyser av dette materialet søker å besvare hvilke samtalemønstre som finnes når lærer og elever i norsk skole samtaler om modelltekster, og med utgangspunkt i analysene diskutere kvalitetstrekk ved modelltekstsamtaler. 


\section{Tilgang til språk}

Bruken av modelltekster bygger på Basil Bernsteins (1971, 1973, 1975, 1990) forskning om språk og sosial kontekst. Bernsteins kodeteorier, at ulike sosiale lag har tilgang til ulike typer språk, har hatt direkte innvirkning på bruken av modelltekster. Bernstein hevdet at barn som vokser opp i miljø med få sjangrer kun får tilgang til det han kaller en snever (restricted) språkkode, mens barn som møter ulike typer tekster får tilgang til langt flere eller videre (elaborated) språkkoder. Bruken av ulike modelltekster skal ifølge Bernsteins teori sørge for at alle elever i et klasserom får tilgang til et sett av språkkoder. Framveksten av sjangerskolen i Australia fikk, med utgangspunkt i Bernsteins teorier, et sosialpolitisk siktemål. Målet var å gi elevene en bedre tilgang til verden gjennom møter med et større spekter av sjangrer (Cope \& Kalantzis, 1993).

Bruken av modelltekster skal bidra til at elevene, i tillegg til sine primære diskurser i hjemmet, også får tilgang til sekundære diskurser i skolen (Gee, 2003). Elevene kommer til skolen med sine primærdiskurser, som samtalen rundt middagsbordet og tekstmeldinger til venner. I slike primærdiskurser er et godt utviklet hverdagsspråk nok til å kunne gjøre seg forstått. I skolen møter elevene et sett av sekundærdiskurser som er lenket til fagrelevante måter å lese og skrive på. Disse sekundære diskursene, eksempelvis den litterære samtalen og de argumenterende tekstene, krever andre uttrykksmåter enn de som kjennetegner primærdiskursen. Sekundærdiskursene krever kjennskap til et fagspråk, både for at eleven skal kunne klare å gjøre seg forstått, men også fordi ulike fag produserer kunnskap gjennom språk (Martin, 1998; Shanahan \& Shanahan, 2008). Eksempelvis er naturfaget kjent for sin presise og kompakte språkbruk preget av mange faglige uttrykk (f.eks. fotosyntese og konkav linse), passivkonstruksjoner (f.eks. begeret fylles med vann) og nominaliseringer (f.eks. verb som blir gjort om til substantiv: fordamping). Slike uttrykksmåter er ikke like dominerende i fag som norsk og historie. En slik måte å forstå sammenhengen mellom faglig utvikling og språk kalles gjerne for disciplinary literacy (Shanahan \& Shanahan, 2008), eller i norsk språkdrakt: fagspesifikk lese- og skriveopplæring (Hoem, Håland \& Skartveit, 2015). Modelltekster kan gi eksempler på fagenes bruk av språk, og de eksemplifiserer hvordan fagspesifikke skrivemåter i sekundærdiskursen kan, eller bør, se ut.

Modelltekster skal ikke bare gi tilgang til et bredt spekter av sjangrer og tekster fra ulike diskurser; samtaler om modelltekster skal også gi kunnskaper om språk. Gjennom studier av modelltekster skal elevene få tilgang til et språk å snakke om teksters språkbruk med, eksempelvis hvordan tekstene er konstruert og hvordan de virker på oss som lesere. Det å snakke om tekster krever gjerne et metaspråk, et språk til å snakke om språk. Eksempler på metaspråk kan være begreper som setning, forfelt, nominalisering eller argument. Studier av modelltekster skal gi elevene tilgang til et slikt metaspråk. Et metaspråk om tekster er altså viktig fordi det gir et verktøy til å snakke om tekster, og det er nødvendig når en skal avdekke teksters skrivemåter. Et metaspråk om tekster gjør det mulig 
å løfte elevenes tenking omkring tekster (Gibbons, 2009), som igjen kan avsløre tekstmønstre som er dominerende, utfordrende eller provoserende. Flere forskere har likevel hevdet at bruken av modelltekster i for liten grad utnytter potensialet til å studere tekster kritisk, og i stedet blir brukt til å reprodusere sjangrer (Callaghan, Knapp \& Noble, 1993; Luke, 1994).

\section{Tekster i dialog og dialog med utgangspunkt i tekster}

Å bruke modelltekster bygger på en tanke om at tekster er i dialog med hverandre og at alle ytringer er fulle av gjenklanger av andre ytringer (Bakhtin, 1998 [1979]). Disse gjenklangene kan kalles intertekstualitet (Kristeva \& Moi, 1986) når de viser seg som tekstlige spor fra en tekst til en annen tekst. Bruken av modelltekster i skolen har nettopp til hensikt å stimulere elevene til å låne tekstlige uttrykk fra andres tekster i produksjon av egne tekster. På den måten hviler bruken av modelltekster på læringsteorier som vektlegger imitasjon og transformasjon som et grunnlag for læring (Vygotskij \& Cole, 1978). Imitasjon kommer til uttrykk når en etterligner eller kopierer språklige mønstre, mens transformasjon betyr at et språklig uttrykk blir overført til et annet språklig uttrykk (Kress, 2003), eksempelvis at en fagtekst gjøres om til en tegneserie. Selve intertekstualiteten, eller bruken av tekstlige trekk, kan derfor vise seg både som direkte lån og som omforminger av modelltekster.

Modelltekstene skal fungere som læringsstøtte, eller stillas (Wood, Bruner \& Ross, 1976) i elevenes skriving. De australske literacyforskerne Jennifer Hammond og Pauline Gibbons (2001) skiller mellom stillasbygging på mikronivå og stillasbygging på makronivå. Stillasbygging på mikronivå er knyttet til selve interaksjonen mellom lærer og elever, mens stillasbygging på makronivå er knyttet til måten å organisere undervisningen på. Bruken av modelltekster kan en forstå som stillasbygging på både makro- og mikronivå fordi didaktikken er en måte å organisere undervisningen på (makro) der samtaler og interaksjoner mellom lærer og elever inngår (mikro). I sjangerskolen inngår et sett av stillaser, gjerne illustrert i følgende trinn: 1. bygging av bakgrunnskunnskaper, 2. dekonstruksjon av modelltekst, 3 . felles konstruksjon av tekst før elevene skriver tekst selv. En slik oppbygging blir omtalt som «the curriculum circle» (Hammond, Burns, Joyce, Brosnan \& Gerot, 1992; Martin \& Rothery,1980, 1981), senere kalt for «teaching learning cycle» (Rothery, 1994) og bærer navnet «sirkelen for læring og undervisning» i norsk språkdrakt (Skrivesenteret). En stor og viktig del av denne støtten innebærer en grundig dekonstruksjon av modelltekst (Callaghan \& Rothery, 1988; Cope \& Kalantzis, 1993; Rose \& Martin, 2013). En dekonstruksjon av modelltekst kan ha form som en analyse av språket i en tekst, gjerne som en muntlig samtale. Slike dekonstruksjoner omtales som fokusert lesing av fagtekster (Macken-Horarik, 1998, s. 82). Læreren leder elevenes oppmerksomhet mot bestemte skriftlige trekk i teksten og peker ut noen kjennetegn på ulike typer tekster og sjangrer. Disse tekstsamtalene følger gjerne faste mønstre i sjangerskolen hvor læreren styrer elevenes oppmerksomhet mot be- 
stemte deler av teksten. En slik dekonstruksjon kan framstå som en streng form for samtale (Maagerø, 2015), med et klassisk IRE-mønster (Initiere - Respons Evaluere) (Cazden, 1988). Læreren stiller et spørsmål (initierer) som elevene responderer på, og elevenes svar blir så evaluert av læreren. Eva Maagerø (2015, s. 41) beskriver samtaleobservasjoner fra australske skoler der læreren stiller lukkede spørsmål til tekstelementer setning for setning: «I den neste setningen er det en metafor. Hvilken?» Mine egne erfaringer etter observasjoner av modelltekstsamtaler på New Zealand og kurs med australske språkdidaktikere befester dette inntrykket av en streng samtaleform i møte med modelltekster. Det klassiske IRE-mønsteret har fått mye kritikk, blant annet av den australske literacyforskeren Pauline Gibbons. Hun mener at den klassiske IRE-samtalen vil gi langt større læringsutbytte om læreren stiller utdypings- eller oppfølgingsspørsmål til elevenes responser, det hun kaller follow up (Gibbons, 2009, s. 144). Et follow up, eksempelvis i form av et utdypingsspørsmål, gir en IREFstruktur som gjør samtalene mer dialogiske og språkstimulerende, mener hun.

\section{Dialogisk undervisning}

Samtaler om modelltekster kan også være en del av større dialogiske kommunikative systemer. Både Robin Alexander, Phil Scott og Hilary Asoko, Douglas Barnes og Martin Nystrand er opptatt av kommunikative systemer som skal lede til dialogisk undervisning. Med utgangspunkt i studier av klassesamtaler fra ulike land presenterer Robin Alexander termen dialogisk undervisning (dialogic teaching) (2006). Han argumenterer for undervisning som har til hensikt å stimulere barns tenking og læring gjennom muntlige undervisningsformer (Alexander, 2006). Dialogisk undervisning kjennetegnes av at den har en hensikt, den er kollektiv, gjensidig, støttende og kumulativ (Alexander, 2008). Undervisningen har en hensikt når læreren planlegger og leder samtaler mot et felles læringsmål. Det kollektive kjennetegnes av at lærer og elever arbeider med læringsoppgaver i fellesskap. Et tegn på at undervisningen er gjensidig, er at lærere og elever lytter til hverandre og deler ideer. En støttende undervisning kjennetegnes av at elevenes ytringer blir tatt på alvor og at fellesskapet tar ansvar for å finne gode løsninger på felles problemstillinger. Kumulativ betyr at lærer bygger videre på den kunnskapen som elevene allerede har.

Også Phil Scott og Hilary Asoko (2006) har utviklet ulike begreper for samtalerepertoar. De har studert dialogiske mønstre i klasseromssamtaler i naturfag. Scott og Asoko (2006) tar utgangspunkt i to dimensjoner av språklige mønstre mellom lærer og elever presentert av Eduardo Mortimer og Phil Scott (2003), nemlig interaktive og ikke-interaktive, autoritative og dialogiske mønstre. Disse dimensjonene generer fire typer klasseromskommunikasjon (Scott \& Asoko, 2006, s.159; Mercer \& Dawes, 2014, s. 438):

1. interaktiv og dialogisk: lærer og elever skisserer et sett av ideer

2. ikke-interaktiv og dialogisk: lærer viser til ulike synspunkter 
3. interaktiv og autoritativ: lærer fokuserer på et bestemt perspektiv gjennom spørsmål og samtale med elevene

4. ikke-interaktiv og autoritativ: læreren presenterer et bestemt synspunkt

Scott og Asoko (2006) understreker at den ene klasseromskommunikasjonen ikke nødvendigvis er bedre enn den andre, men at det er balansen mellom dem som er viktig. Noen ganger kan en ikke-interaktiv og autoritativ lærerstemme som forklarer, være det som gir grunnlaget for læring. Mens andre ganger kan nettopp det at elevene selv uttrykker sin forståelse sammen med andre elever og med læreren som aktiv lytter, føre til en dypere forståelse av kunnskapen. Det er naturfagklasserommet som er utgangspunktet for kategoriene til Scott og Asoko (2006). De mener at den interaktive og autoritative dialogen, hvor læreren får elevenes innspill og det er noe helt bestemt han skal fram til, er den mest dominerende i naturfagsklasserommet (Scott \& Asoko, 2006).

Douglas Barnes skiller mellom presenterende (presentational) og utforskende (exploratory) samtaler (1992 [1976]). Presenterende samtaler er samtaler som fokuserer på et bestemt innhold med noen bestemte svar. I en presenterende samtale blir svarene, eller responsene, evaluert av et bestemt publikum og svarene blir presentert som ferdig gjennomtenkte svar (Barnes, 2008). Mange av samtalene mellom lærer og elev i skolen vil ha et presenterende preg, spesielt når samtalene tar utgangspunkt $\mathrm{i}$ et emne som læreren har undervist $\mathrm{i}$ tidligere og hvor samtalen har som mål å teste elevenes forståelse. Utforskende samtaler derimot, har til hensikt å utforske ideer og sortere egne tanker (Barnes, 2008). De utforskende samtalene kan ha et nølende og mangelfullt utrykk, hevder Barnes. Han understreker også at både presenterende og utforskende samtaler er viktige for læring, men at læreren må vite hva som er forskjellen, samt når det er hensiktsmessig å bruke de ulike formene for samtale (2008). Utforskende samtaler kan for eksempel være hensiktsmessige i starten av et emne, hvor nye ideer skal utforskes (Barnes, 1992 [1976]).

Martin Nystrand (1997) presenterer tre kjennetegn på dialogisk samtale. Det er: autentiske spørsmål, opptak og høy verdsetting. Autentiske spørsmål er spørsmål som læreren ikke vet svaret på, mens opptak vil si at læreren inkorporerer elevens svar i sin respons på elevsvaret. Gjennom slike opptak av elevsvar viser læreren interesse for elevens svar og verdsetter dermed også elevsvaret. Nystrand kaller det for gjentak og høy verdsetting.

Disse kommunikative mønstrene og de ulike typene av samtaler som her er presentert, kan gå noe over i hverandre. Et autentisk spørsmål (jf. Nystrand, 1997) kan samtidig være en del av en utforskende samtale (jf. Barnes, 1992 [1976]) med en bestemt hensikt (jf. Aleksander, 2006) som inngår i et interaktivt og dialogisk samtalemønster (jf. Scott \& Asoko, 2006), men et autentisk spørsmål kan også være en del av en presenterende samtale (jf. Barnes, 1992 [1976]) og inngå i et mer interaktivt og autoritativt kommunikasjonsmønster (jf. Scott \& Asoko, 2006). 


\section{Det teoretiske perspektivet oppsummert}

Oppsummert kan en si at bruken av modelltekster i klasserommet inviterer til dialog mellom tekster (Bakhtin, 1998 [1979]; Kristeva \& Moi, 1986) med den hensikt å støtte elevenes læring og utvikling som skrivere. Bruken av modelltekstene skal gi språklige innsikter og tilgang til sekundærdiskursene (Gee, 2003) og fagspesifikke sjangrer (Shanahan \& Shanahan, 2008). I denne studien knyttes lærerens arbeid med modelltekster til undersøkelse av tekstsamtaler; derfor er teorier om kommunikasjonsmønstre (Alexander, 2006; Scott \& Asoko, 2006) og ulike typer av samtaler (Barnes, 1992 [1976]; Gibbons, 2009; Nystrand, 1997) en viktig del av det teoretiske bakteppet.

\section{Metode}

Denne artikkelen henter sitt materiale fra en større kvalitativ kasusstudie som blant annet undersøkte hvordan elever på 5. trinn anvendte språklige inspirasjoner og mønstre fra modelltekster de fikk møte i undervisningen (Håland, 2013). I studien skrev de 43 elevene flere saktekster med utgangspunkt i modelltekster. En av disse saktekstene var å skrive en individuell fagbok som handlet om Det gamle Egypt. Boka skulle elevene presentere for andre elever på skolen og stille ut i biblioteket. I forkant av arbeidet med fagboka studerte elevene forskjellige modelltekster som alle hadde det til felles at de var hentet fra fagbøker skrevet for barn av anerkjente norske og internasjonale forfattere. To av disse modelltekstene var Insekter. Norsk naturleksikon for barn av Leif Ryvarden (2000) og Skarpe tenner av Erna Osland (2005). Modelltekstene ble valgt fordi de er eksempler på populærvitenskapelig formidling til barn, og fordi de bruker ulike språklige virkemidler til å formidle fagstoffet. Mens boka til Ryvarden har en tradisjonell inndeling med hoved- og underoverskrifter, bruker Osland litterære virkemidler, slik som eksempelvis allitterasjon i overskrifter, gjentakelser, sammenlikninger og direkte henvendelser til leseren, når hun formidler fagkunnskaper til barn.

Læreren ble valgt fordi hun var interessert og uredd og kunne tenke seg å gå inn i et lengre samarbeid med en forsker. Rollene våre var fordelt slik at jeg valgte ut modelltekstene og kom med forslag til hvilke språklige elementer som læreren kunne fokusere på. For hver ny modelltekstintroduksjon hadde vi egne møter der vi kikket på modelltekstene og samtalte om de ulike språklige trekkene. Læreren fikk ingen manual for hvordan hun skulle samtale om tekstene, men jeg uttrykte et ønske om at de skulle studere modelltekstene med et åpent og inviterende utgangspunkt. Vi modellerte noen spørsmål sammen, slik som «Hva er det forfatteren gjør når han skriver om dette faglige emnet? Hvordan er det han prøver å få meg interessert i fagstoffet? Hvorfor tror du han har valgt å gjøre det slik?» Spørsmålene skulle legge til rette for at elevene kunne gjøre oppdagelser i modelltekstene. 
Artikkelen bygger på analyser av klassens tekstsamtaler med utgangspunkt i bøkene til Ryvarden (2000) og Osland (2005). Tekstmønstrene som elevene samtalte om, og som det refereres til i utdragene i denne artikkelen, er knyttet til bruken av overskrifter: hovedoverskrifter, underoverskrifter, overskrifter formet som spørsmål og overskrifter formet som allitterasjon. Dette er bare en liten del av materialet. Jeg har valgt denne delen av materialet fordi samtaler om ulike typer overskrifter var ny kunnskap for elevene, men samtidig ganske konkret for denne aldersgruppen. Elevene kunne selv velge hvilke tekstlige trekk de ønsket å bruke, og de kunne også la være å bruke dem, når de senere skulle skrive sine egne fagbøker.

Tekstsamtalene ble filmet, transkribert i form av nedskrevet tale og siden analysert. Transkripsjonen er gjort på nynorsk med unntak av noen elevutsagn der eleven har diktert på bokmål. Analysen vektlegger samspillet mellom lærer og elever i møte med modelltekstene, og analyseoptikken er utviklet med utgangspunkt i Alexander (2006), Barnes (1992 [1976]), Gibbons (2009), Nystrand (1997) samt Scott og Asoko (2006) sine teorier om samtalemønstre. Konkrete analysekategorier var derfor: autentiske spørsmål, opptak og høy verdsetting (jf. Nystrand, 1997), dialogisk undervisning (jf. Alexanders fem punkter, 2006), interaktive, ikke-interaktive, autoritative og dialogiske samtalemønstre (jf. Scott \& Asoko, 2006), presenterende og utforskende samtalemønstre (jf. Barnes, 2008) og IREF-mønster (jf. Gibbons, 2009). Analysekategoriene er presentert i tabell 1 , slik jeg har brukt dem i arbeidet med materialet:

Tabell 1. Analysekategorier

\begin{tabular}{|l|l|l|}
\hline $\begin{array}{l}\text { Kommunikative } \\
\text { mønstre }\end{array}$ & $\begin{array}{l}\text { Alexander } \\
\text { (2006) }\end{array}$ & $\begin{array}{l}\text { Hensikt: Samtalen har et bestemt mål, f.eks. studere ulike } \\
\text { overskrifter. } \\
\text { Kollektiv: Studiet skjer i fellesskap. } \\
\text { Gjensidig: Lytter til hverandres oppdagelser og deler ideer. } \\
\text { Støttende: Elevenes ytringer blir hørt og verdsatt. } \\
\text { Kumulativ: Læreren bygger videre på den kunnskapen elevene har, } \\
\text { eksempelvis om språk. }\end{array}$ \\
\cline { 2 - 4 } & $\begin{array}{l}\text { Scott \& } \\
\text { Asoko } \\
(2006)\end{array}$ & $\begin{array}{l}\text { Interaktiv og dialogisk: Lærer og elever stiller spørsmål og utforsker } \\
\text { ideer sammen. } \\
\text { Ikke-interaktiv og dialogisk: Lærer stiller spørsmål og tillater mange } \\
\text { responser fra elevene. } \\
\text { Interaktiv og autoritær: Lærer stiller spørsmål til elevene, men er på } \\
\text { jakt etter bestemte svar. } \\
\text { Ikke-interaktiv og autoritær: Lærer presenterer et bestemt synspunkt } \\
\text { uten å invitere elevene til å uttrykke sine responser. }\end{array}$ \\
\hline Dialogiske \\
samtalemønstre & $\begin{array}{l}\text { Barnes } \\
\text { (2008) }\end{array}$ & $\begin{array}{l}\text { Presenterende samtaler: Læreren har fokus på et bestemt innhold } \\
\text { med bestemte svar. } \\
\text { Utforskende samtaler: Læreren har fokus på et bestemt innhold med } \\
\text { mange mulige svar. }\end{array}$ \\
\cline { 2 - 4 } & $\begin{array}{l}\text { Gibbons } \\
\text { (2009) }\end{array}$ & $\begin{array}{l}\text { IREF-struktur: lærer initierer spørsmål - eleven responderer - lærer } \\
\text { evaluerer elevens svar - følger opp elevens svar med et utdypende } \\
\text { spørsmål }\end{array}$ \\
\cline { 2 - 4 } & $\begin{array}{l}\text { Nystrand } \\
\text { (1997) }\end{array}$ & $\begin{array}{l}\text { Autentisk spørsmål: Et spørsmål som læreren ikke vet svaret på. } \\
\text { Opptak: Lærerens inkorporering av elevens svar i sin respons. } \\
\text { Høy verdsetting: Interesse og verdsetting av elevens svar. }\end{array}$ \\
\hline
\end{tabular}


Noen av analysekategoriene kan være overlappende, et IRE-mønster kan samtidig være et eksempel på en ikke-interaktiv og autoritativ samtale, og et IREF-mønster kan inngå i et utforskende samtalemønster. De ulike begrepene kan gi en optikk til å se forskjellige mønstre av kommunikasjon i klasserommet. Analysene har til hensikt å undersøke hvilke samtalemønstre som brukes når elever og lærere samtaler om modelltekster, dette for å kunne diskutere kvalitetstrekk ved samtalemønstrene når en dekonstruerer modelltekster.

\section{Analyse og resultat}

I det følgende analyseres samtaleutdragene. Samtalene er hentet fra dekonstruksjonen av Leif Ryvardens Insekter. Norsk naturleksikon for barn (2000) og Erna Oslands Skarpe tenner (2005). Jeg gjør oppmerksom på at alle elevene har fiktive navn i samtaleutdragene.

\section{Samtalemønstre med utgangspunkt i Leif Ryvardens tekst}

Boka Insekter. Norsk naturleksikon for barn av Leif Ryvarden beskriver ulike kjennetegn på insekter. Kompositorisk har boka en klassisk oppbygning bestående av hovedoverskrifter med tilhørende underoverskrifter. Noen av overskriftene er formet som spørsmål. I tekstsamtalen under er det nettopp hovedoverskrifter, underoverskrifter og hovedoverskrifter formet som spørsmål læreren fokuserer på, og som var målet for dekonstruksjonen av modellteksten.

Lærer: No skal vi sjå korleis forfattaren har delt opp stoffet sitt. No fann eg ei side som ser slik ut. Og når de ser denne sida her, så ser de ... kva trur de desse to sidene handlar om?

Stig: Vanlege insekt.

Lærer: Korleis veit du det?

Stig: Det står.

Lærer: Det står. Det er ei hovudoverskrift, ser de det? Ei hovudoverskrift som heiter «Våre vanlegaste insekt», og då veit vi, som Stig seier, at desse to sidene handlar om dei vanlegaste insekta. Hovudoverskrifta er «Våre vanlegaste insekt».

Klassen studerer ulike hovedoverskrifter før læreren så leder oppmerksomheten over mot underoverskriftene.

Lærer: (...) ser de at det er overskrifter på dei òg? Desse overskriftene, er dei like store som hovudoverskrifta? Eli?

Eli: Det er underoverskrifter.

Lærer: Det er underoverskrifter. Ser de boka er delt inn i ... det er ei hovudoverskrift som fortel kva desse sidene handlar om, og så er det underoverskrifter, for kvart dyr.

Læreren leder så oppmerksomheten fra modellteksten til den teksten som elevene selv skal skrive. 
Lærer: (...) Dersom de skulle ... lat oss no tenkje oss at de skulle skrive om Egypt, at de skulle lage ei fagside ${ }^{1}$ om Egypt, kva kan dykkar hovudoverskrift då vere? Ei eller anna hovudoverskrift. Same kva ... Vegard?

Vegard: Det gamle Egypt.

Lærer: «Det gamle Egypt» vil du ha som hovudoverskrift. Kva vil du ha som underoverskrift på den sida der?

Vegard: Bustader, ørken.

Lærer: «Det gamle Egypt» vil du ha som hovudoverskrift, (...) Er det nokon andre som kjem på ei anna hovudoverskrift? Det er mange moglegheiter, det er heilt sikkert.

Læreren griper fatt i en av hovedoverskriftene som en av guttene foreslo da de samtalte om hovedoverskrifter. Det er hovedoverskriften «Store byggverk».

Lærer: Ja. Om vi tek «Store byggverk», kva ville du hatt som overskrift då?

Morten: Statuer.

Lærar: Ja! Flott! Terje?

Terje: Pyramidar.

Lærar: Ja. Pyramidar ville du hatt som underoverskrift ... (ein elev seier «Tempel») ... og tempel. Ja, så bra! Hovudoverskrifta er «Store byggverk» (...) Underoverskriftene er «Pyramidar», det er «Tempel» og det er «Statuar».

Elevene kommer med mange forslag til hovedoverskrifter og tilhørende underoverskrifter før læreren leder oppmerksomheten over på overskrifter formet som spørsmål.

Lærer: (...) Kva vil de seie om denne overskrifta då: «Korleis beskyttar insekta seg?»

Sven: Det er eit spørsmål.

Lærer: Det er eit spørsmål, ja. Det går svært godt å ha spørsmål i overskriftene. (...)

Dersom de skulle ha eit spørsmål i ei overskrift i ei fagbok om Egypt, kva for

spørsmål kunne de då ha laga?

Gro: Hvorfor bygget de pyramider?

Lærer: Ja, svært bra, Gro. Kvifor dei bygde pyramidar, er verkeleg noko vi kan undrast over. Kvifor gjorde dei det? Bra! «Kvifor bygde dei pyramidar?». Det kunne ha vore ei slik hovudoverskrift. Flott, kjem de på nokre andre spørsmål som kunne ha vore hovudoverskrift?

\section{Fra et autoritativt til et dialogisk samtalemønster}

Læreren styrer klassens samtale mot tre sentrale trekk ved denne modellteksten: hovedoverskrifter, underoverskrifter og overskrifter formet som spørsmål. Samtalen veksler mellom interaktiv-autoritativ, hvor læreren styrer samtalen mot et bestemt mål, og interaktiv-dialogisk, hvor lærer og elever utforsker ideer sammen (jf. Scott \& Asoko, 2006). Når læreren vil fokuserer på bestemte kjennetegn i teksten, slik som overskrifter og overskrifter formet som spørsmål, blir spørsmålene gjerne lukkede og inautentiske fordi læreren vet svaret selv: «Kva vil de seie om denne underskrifta då: "Korleis beskyttar insekta seg?"». Slik framstår samtalen som autoritativ, men interaktiv fordi elevene blir bedt om å reflektere over tekst. Når læreren fokuserer på den teksten som elevene selv skal skrive, får samtalen et interaktivt og dialogisk preg. Læreren stiller autentiske 
spørsmål som hun ikke vet svaret på, eksempelvis: «Dersom de skulle ... lat oss no tenkje oss at de skulle skrive om Egypt, at de skulle lage ei fagside om Egypt, kva kan dykkar hovudoverskrift då vere?», «Om vi tek "Store byggverk", kva ville du hatt som overskrift då?» og «Dersom de skulle ha eit spørsmål i ei overskrift i ei fagbok om Egypt, kva for spørsmål kunne de då ha laga?». Den interaktive og dialogiske samtalen blir i langt større grad preget av dialogisk samhandling fordi elevene kommer med en rekke innspill på disse åpne og autentiske spørsmålene.

\section{Både IRE- og IREF-mønster}

Selv om disse samtaleutdragene i stor grad må sies å ha et IRE-mønster hvor læreren stiller spørsmål, elevene responderer og læreren evaluerer svarene deres for eksempel i form av «Flott!» og «Ja, svært bra.», inneholder også samtalen mange dialogiske mønstre, slik som bruk av autentiske spørsmål, opptak, høg verdsetting (jf. Nystrand, 1997) og IREF-struktur (jf. Gibbons, 2009). Spørsmål som «Om vi tek "Store byggverk", kva ville du hatt som overskrift då?» og «Dersom de skulle ha eit spørsmål i ei overskrift i ei fagbok om Egypt, kva for spørsmål kunne de då ha laga?» er, som tidligere nevnt, eksempler på autentiske spørsmål. Akkurat disse autentiske spørsmålene har til hensikt å bringe fram ideer hos elevene, ideer til deres egen skriving. Elevene responderer på spørsmålene og læreren bruker i stor grad opptak av elevsvar. Noen ganger er opptakene enkeltelevers utsagn: «"Det gamle Egypt" vil du ha som hovedoverskrift.» og «"Pyramidar" ville du hatt som underoverskrift». Andre ganger inkorporerer læreren flere elevers utsagn i opptaket: «Hovudoverskrifta er "Store byggverk" (...) Underoverskriftene er "Pyramidar", det er "Tempel" og det er "Statuar"». Elevenes svar blir på denne måten verdsatt av læreren gjennom opptak og høy verdsetting (jf. Nystrand, 1997). Noen ganger ber læreren også om utdypinger gjennom sine oppfølgingsspørsmål (jf. follow-up), eksempelvis «Korleis veit du det?» og «Kva vil du ha som underoverskrift på den sida der?» (jf. IREF-struktur, Gibbons, 2009). Oppfølgingsspørsmålene er også et tegn på at læreren tar elevens svar på alvor og verdsetter hans svar (jf. Nystrand, 1997).

\section{Bruken av autentiske og inautentiske spørsmål: Ulike hensikter}

Spørsmålstypene har ulike hensikter (jf. Alexander, 2006) i modelltekstsamtalene. Gjennomgående i materialet kan det se ut som om de inautentiske spørsmålene har til hensikt å sette fokus på noen helt bestemte tekstlige trekk, som for eksempel hovedoverskrifter formet som spørsmål, mens de autentiske spørsmålene har til hensikt å la elevene overføre de språklige særtrekkene i modelltekstene til sin egen tekst. På en måte kan en si at de lukkede inautentiske spørsmålene har til hensikt å la elevene oppdage språklige trekk i tekstene, mens de åpne og autentiske spørsmålene har til hensikt å utforske og transformere tekstmønstre (jf. Kress, 2003). 


\section{Samtalemønstre med utgangspunkt i Erna Oslands tekst}

Da elevene studerte Skarpe tenner av Erna Osland, hadde de blant annet fokus på Oslands bruk av allitterasjon i overskrifter. Læreren leste en av Oslands overskrifter høyt, «Tenna på tørk», og elevene responderte umiddelbart med latter.

Lærer: (...) Tenner på tørk. Kan de seie noko om den overskrifta? Kva synest de, kva tenkjer de om den? Eli?

Eli: Ho er litt sånn merkeleg. Litt løyen og merkeleg.

Lærer: Ho er litt rar, merkeleg og løyen, eg synest òg det. Du legg merke til henne.

Med ein gong legg du merke til henne. Dei har gjort noko spesielt her med denne overskrifta. Er det nokon som kan sjå kva som er litt spesielt? Tenner på tørk, tenner på tørk.

Læreren vil ha elevene til å legge merke til at ordene begynner på samme bokstav, men elevene kommenterer ikke dette. Læreren kommenterer det derfor selv på denne måten:

Lærer: Eg kan fortelje dykk at den overskrifta der, i den så er det noko som heiter allitterasjon. Nokon som veit kva det er? Allitterasjon. Ser de at dei to orda byrjar med same bokstav? T byrjar dei med. T, er det konsonant eller vokal? Vegard?

Vegard: Konsonant.

Lærer: Ein konsonant. Allitterasjon, då byrjar fleire ord på same konsonant. Tenner på tørk. Det var allitterasjon, eit litt vanskeleg ord.

Læreren finner flere overskrifter i modellteksten som har allitterasjon. Disse leser hun høyt for klassen:

Lærer: Fæle fiskar. Kva kan vi seie om den?

Hans: Det byrjar på dei same konsonantane.

Lærer: Det òg var same konsonant. Og kva for konsonant var det? Det var $\mathrm{f}-\mathrm{f}$. Fæle fiskar. Kvifor trur de at ho Erna Osland, som har skrive denne boka, kvifor har ho brukt slik allitterasjon? Tann og tryne, tenner på tørk. Kvifor har ho det, Gro?

Gro: Legge merke til henne.

Lærer: Legg merke til henne [overskrifta]. Ja, trur du ho var medviten om at det blei slik når ho laga overskriftene?

Eli: Det skal nok vere litt slik (...) litt ekstra morosamt. Slik at born synest det er kjekt å lese henne.

Læreren styrer elevenes oppmerksomhet ikke bare mot allitterasjon som et språklig fenomen, men mot allitterasjon som virkemiddel i denne bestemte teksten. Elevene gir uttrykk for relevante tolkninger av virkemiddelet: «Det skal nok vere litt slik (...) litt ekstra morosamt. Slik at born synest det er kjekt å lese henne». Likevel går det en liten stund før elevene greier å transformere Erna Oslands allitterasjoner til allitterasjoner i de tekstene som elevene selv skal skrive om det gamle Egypt. Noen foreslår «Balsamert lik» og læreren spør om det er allitterasjon. Læreren gir elevene støtte ved å ta utgangspunkt i ordet mumie, og sammen forsøker de å finne et ord på bokstaven M som kan bli til en allitterasjon. 
Lærer: (...) Eit ord som byrjar på m, som vi kan bruke i samband med mumie? Kjem de på noko?

(...)

Sven: Mørkets mumier.

Lærer: Mørkets mumier. Ja, kva tenkjer du då?

Sven: Skummelt.

Lærer: Mørkets mumier, det er litt slik, UÆHH! Er det ikkje det? Viss vi tenkjer på mumiar, så er det litt skummelt og spennande, er det ikkje det? Ja, eg tenkte på ein annan òg. Eli?

Eli: Mystisk mumie.

Lærer: Mystisk mumie, det kunne òg ha vore ein slik ein. Mystisk ... Dersom de hadde laga ei hovudoverskrift der det stod «mumier», eller ei der det stod «mørkets mumier». Kva for ei trur de at andre ville ha sett på, at andre hadde fått lyst til å lese? Tone?

Tone: «Mørkets mumier».

Lærer: «Mørkets mumier», det er litt meir spennande, er det ikkje det? Live?

Live: Eg skulle seie ein til slik ...

Lærer: Kom du på ein til?

Live: Mumiens ... kva var det igjen ... «Mumiens makt».

Lærer: «Mumiens makt», det kunne òg ha vore ein slik ein. Svært bra! Farao, då?

Kanskje de har eigne ord? Det er ikkje sikkert de må bruke dei orda eg sleng ut. Å, Eli, du har så lyst til å seie noko! Kom med det!

Eli: «Fantastiske Farao».

Lærer: «Fantastiske Farao», det ramla inn slik hos deg, det såg eg!

Når elevene til slutt har skjønt hva en allitterasjon er, greier de å transformere det språklige uttrykket de har møtt hos Osland til allitterasjoner i sine egne tekster om det gamle Egypt.

\section{Faglig fokuserte samtaler}

Tekstsamtaler som tar utgangspunkt i modelltekster, har et bestemt faglig fokus (jf. Macken-Horarik, 1998). I eksempelet over er det bruken av allitterasjon i overskrifter som står i sentrum. Elevene kan ikke det faglige utrykket «allitterasjon», og derfor må læreren gi elevene den faglige termen: «Eg kan fortelje dykk at den overskrifta der, i den så er det noko som heiter allitterasjon.». Den fokuserte samtalen om modellteksten forsøker å gi elevene et språk til å snakke om tekster med. Læreren bruker både ord som konsonanter og allitterasjon, og elevene begynner også etter hvert å ta disse ordene i bruk: «Det byrjar på dei same konsonantane.» Slik blir samtalen kumulativ (jf. Aleksander, 2006) fordi læreren bygger videre på elevenes kunnskaper om språk. Samtalen fokuserer på den faglige termen «allitterasjon», hvordan allitterasjonen kommer til uttrykk og hvilken funksjon den har på leseren i denne modellteksten. Slik er det ikke bare språket i seg selv som er i fokus, men språkets funksjon i en kontekst. Det faglige metaspråket ser ut til å gi elevene tilgang til et analytisk blikk på teksten og å løfte tenkingen omkring språkets funksjon i tekster (Gibbons, 2009), i dette tilfellet allitterasjoners virkning på leseren i denne modellteksten. 


\section{Fra presenterende til utforskende samtaler}

Samtalene om modelltekstene har ofte en presenterende innledning for så å gå over til mer språklig utforsking. I eksempelet over velger læreren først å presentere eksempler på allitterasjon, høre elevenes umiddelbare reaksjon, for deretter å rette oppmerksomheten mot allitterasjonens språklige side: «Fæle fiskar. Kva kan vi seie om den?». I starten er altså samtalen rimelig presenterende (jf. Barnes, 2008). Samtalen er rettet mot noe bestemt, nemlig allitterasjoner i overskrifter. Siden blir samtalen mer utforskende (jf. Barnes, 2008) idet den når et nivå hvor elevene sorterer og utforsker mulige allitterasjoner i sine egne tekster: «Mørkets mumie», «Mumiens makt», «Fantastiske farao». Samtidig synes jeg at hele samtaleseansen har et utforskende preg sammenliknet med de strenge tekstsamtalene som finnes i australsk litteratur (jf. Maagerø, 2015). I tråd med australsk dekonstruksjon av modelltekst kunne læreren sagt: «I den neste setningen er det en allitterasjon. En allitterasjon betyr at ord begynner med samme lyd. Kan dere finne allitterasjonen?». Det er slik mange av tekstsamtalene i australsk modelltekstdidaktikk fungerer (jf. Maagerø, 2015), og det er denne formen for tekstsamtale denne artikkelen søker å tilby et alternativ til.

\section{Samtalemønstre - oppsummert}

Alle samtalene skjer i et kollektiv med lærer og elever som gjensidig støttende. Samtalene om modelltekstene beveger seg gjerne fra en presenterende innledning for så å gå over til en mer utforskende del. Alle samtaleutdragene har et klart definert faglig fokus og en bestemt hensikt. Spørsmålene som læreren stiller er både autentiske og inautentiske, men spørsmålene har forskjellige hensikter i møte med modelltekstene. Undervisningen har både et interaktivt autoritativt mønster preget av IRE-samtale og et interaktivt dialogisk mønster med innslag av IREF-mønster.

Samtaleutdragene er noe avgrenset på den måten at de er knyttet til et bestemt klassetrinn (5. trinn) og en bestemt skrivesituasjon (individuell fagbok om Det gamle Egypt). Samtalene utgjør dessuten bare deler av et større undervisningsopplegg som inneholdt enda flere modelltekster, og som hadde et fokus på flere tekstlige trekk. Samtaleutdragene som er vist, kan ikke si noe generelt som kjennetegner alle samtaler om modelltekster i skolen, men utdragene gir likevel muligheter til å diskutere hvordan vi kan forstå kvalitetstrekk i modelltekstsamtaler som et alternativ til sjangerskolens strenge tekstsamtaler.

\section{Diskusjon - to mønstre av interaksjon}

Samtalemønstrene som er analysert over, går fra en oppdagende til en utforskende del. I noen deler av tekstsamtalene er målet at elevene skal oppdage tekstlige mønstre, mens i andre deler av samtalene er fokuset på utforsking av språklige trekk. Tekstsamtalene har ofte et oppdagende preg i starten: Elevene skal 
oppdage språklige trekk og læreren styrer elevenes oppmerksomhet inn mot disse språklige trekkene. Vi har sett at de oppdagende innledende samtalene kan være preget av et IRF-mønster og inngå i et interaktivt-autoritativt samtalemønster (jf. Scott \& Asoko, 2006) eller ha en presenterende form (Barnes, 1992 [1976]), men de har til hensikt at elevene skal gjøre språklige oppdagelser, se uttrykksmåter i tekster og ikke bare respondere på lærerens oppdagelser. Derfor vil de oppdagende samtalene har færre spor av dialogiske mønstre enn det som er tilfelle for de mer utforskende delene av tekstsamtalene.

Mange elever trenger å oppdage og identifisere språklige trekk i en tekst for å kunne bruke de tekstlige mønstrene selv (Håland, 2013). Men elevene vil ofte trenge en form for støtte for å kunne gjøre oppdagelser (jf. Hillocks, 1986; Stolarek, 1994). Lærerens spørsmål kan fungere som en slik form for støtte og døråpner slik at elevene i det hele tatt kan klare å oppdage språklige trekk ved modelltekstene. Gjennom spørsmål kan læreren gi elevene muligheter til å oppdage tekstlige elementer og måter å uttrykke seg på. Slike oppdagende tekstspørsmål kan være: «Legger dere merke til noe spesielt ved måten denne teksten er skrevet på?» eller «Hvordan er den organisert? Hva kan vi si om ordvalget?». Denne typen oppdagende spørsmål kan gi tilgang til et metaspråklig perspektiv på tekster som kan hjelpe elevene å snakke om teksten på en analytisk måte som kan løfte tenkingen (jf. Gibbons, 2009). De oppdagende spørsmålene kan også avdekke språklige mønstre som kan gi tilgang til et sett av språklige koder (jf. Bernstein, 1975), og som kan representere fagspesifikke skrivemåter (jf. Shanahan \& Shanahan, 2008) i ulike sekundærdiskurser (Gee, 2003).

Når elevene har oppdaget språklige trekk, kan disse utforskes, gjerne gjennom ulike typer av transformasjoner til egen tekstskriving. Vi har i analysene sett at når elevene utforsker skrivemåter, får tekstsamtalen et langt mer dialogisk preg bestående av utforskende og autentiske spørsmål (jf. Nystrand, 1997) som inngår i et interaktivt dialogisk mønster (jf. Scott \& Asoko, 2006). Også for å utforske språklige elementer trenger elevene lærerens støtte, gjerne i form av spørsmål som gir muligheter for utforsking. Eksempel på slik spørsmålsstøtte kan være: «Hvordan kan det språklige trekket/virkemiddelet etc. høres ut?» Slik spørsmålsstøtte kan gi elevene muligheter for å modellere og utforske ulike skrivemåter sammen. Gjennom modellering av skrivemåter blir elevenes forslag verdsatt og de metaspråklige utrykkene blir eksplisitte og konkrete, ikke bare teoretiske termer. Et eksempel i dette materialet er begrepet allitterasjon. Begrepet allitterasjon kan gjennom et utforskende spørsmål, som «Hvordan kan en allitterasjon høres ut?», bli transformert til konkrete uttrykk som «Fantastiske farao». I modelltekstdidaktikken vil en viktig del av utforskingen innebære å overføre de språklige tekstelementene til den konkrete teksten elevene selv skal skrive. Utforskende spørsmål kan binde modellteksten og elevenes egen skriving sammen og bidra til et dialogisk og interaktivt klasserom (jf. Scott og Asoko, 2006) hvor elevene framsetter mulige alternativer for sin egen skriving. Jeg velger å kalle spørsmål som binder sammen modellteksten og elevenes egen 
tekst, for overføringsspørsmål, fordi læreren tar utgangspunkt i et trekk ved modellteksten som så overføres til elevens egen tekst (Håland, 2013). Slike overføringsspørsmål kobler også lesingen av modellteksten direkte til elevens egen tekst, og målet med den fokuserte modelltekstlesingen blir tydelig. Dessuten kan det se ut som om bruken av overføringsspørsmål har betydning for om elevene bruker de tekstmønstrene de har hatt fokus på (Håland, 2013). Eksempler på slike overføringsspørsmål kan være: «Dersom du skal lage en underoverskrift i din tekst, hvordan kan den se/høres ut?» Overføringsspørsmålene kan også være tett koblet til fagspesifikke skrivemåter: «Dersom du skal lage en hypotese i labrapporten din, hvordan kan den se ut?» eller «Dersom du vil begynne novellen din in medias res, hvordan kan da første setning være?». Overføringsspørsmålene kan knyttes til ulike sider ved teksten, fra kompositoriske mønstre (f.eks. «Dersom du skal ha en åpen slutt i novella di, hvordan kan den høres ut?») til språklige detaljer (f.eks. «Dersom du skal ha et retorisk spørsmål i din tekst, hvordan kan det se ut?»).

Med støtte i det samtalematerialet som er vist i denne artikkelen, er det tydelig at samtaledidaktikken kan inneholde både en oppdagende og en utforskende del. Den oppdagende delen vil ha færre dialogiske mønstre enn den utforskende fordi den ofte har som mål å avdekke noen helt bestemte språklige elementer, mens den utforskende delen, som navnet tilsier, er mer utforskende og kan gi mange mulige svaralternativer. Men man kunne også tenke seg at samtalen inneholdt en utfordrende del, der de språklige trekkene fra de ulike modelltekstene ble satt opp mot hverandre og diskutert kritisk. Læreren kunne eksempelvis sagt: «Nå har vi sett på ulike overskrifter, hvilke av disse synes du passer best til den teksten du skal skrive?», «Er det noen av disse overskriftene du likte bedre enn andre, og hvorfor det?», «Er det noen overskriftstyper du ikke likte, hvorfor ikke?» og «Er det noen typer overskrifter som du synes passer / ikke passer når du skal lage ei fagbok som skal leses av andre og stilles ut $\mathrm{i}$ biblioteket?». Modelltekstene ble aldri satt opp mot hverandre på en slik måte at elevene diskuterte hvilke skrivemåter de syntes passet best til det aktuelle formålet. Kanskje skyldes det at dette er 10 år gamle elever som ikke er innlemmet i en kultur hvor de stiller spørsmål ved lærerens introduksjoner av skrivemåter, og at de ulike typene overskrifter ikke vekker motstand hos noen av elevene? Men mest av alt skyldes det den metodiske tilnærmingen ved at jeg som forsker ikke var observant nok til å problematisere dette i møte med læreren. Vi diskuterte ikke hvordan vi kunne utfordre modelltekstene.

Modelltekstdidaktikken har møtt kritikk fordi den favoriserer sjangrer som uttrykk for bestemte ideologier (Luke, 1994) og fordi den blir for konsentrert rundt læreren (Kress, 1993). En utfordrende del som en del av dekonstruksjonen, kunne tatt bort noe av denne kritikken. En slik utfordrende del kunne inneholdt spørsmål som: «Hvorfor er denne teksten skrevet slik?», «Hva var formålet med denne teksten?» eller «Finnes det andre skrivemåter som kunne være tilpasset det samme formålet?». 


\section{Konklusjon - Et didaktisk bidrag til samtalen om modelltekster}

Dekonstruksjon av modelltekster er en sentral del av modelltekstdidaktikken og kan ha ulike former. Jeg har med denne artikkelen vist noen konkrete modelltekstsamtaler som har hatt fokus på å oppdage og utforske tekstelementer. Samtalene om modelltekster bør gi elevene muligheter for å oppdage tekstlige mønstre, samt utforske og utfordre dem. Disse tre elementene - oppdage, utforske og utfordre - tenker jeg er kvalitetstrekk ved modelltekstsamtaler. Ulike typer spørsmål vil kunne hjelpe læreren å gi elevene muligheter for å oppdage, utforske og utfordre tekstlige mønstre. Jeg avslutter derfor denne artikkelen med noen konkrete eksempler på spørsmålstyper som kan ivareta disse aspektene i samtaledidaktikken, og som kanskje kan fungere som støtte for alle lærere som skal bruke modelltekster i undervisningen:

Tabell 2. Spørsmål til bruk for å oppdage, utforske og utfordre modelltekster

\begin{tabular}{|l|l|l|}
\hline Oppdage & Utforske & Utfordre \\
\hline Hva legger du merke til i & Hvordan kunne dette språklige & Hvorfor skal du bruke dette \\
teksten (språket, komposisjon, & tekstelementet (overskrifter, & tekstelementet i din tekst? Hva gjør \\
setninger, ordvalg, overskrifter, & retorisk spørsmål etc.) sett ut i & dette tekstelementet med teksten din? \\
bilder, illustrasjoner etc.)? & din tekst? & Kunne du brukt andre tekstmønstre? \\
\hline
\end{tabular}

\section{Om forfatteren}

Anne Håland er førsteamanuensis ved Nasjonalt senter for leseopplæring og leseforskning ved Universitetet i Stavanger.

Institusjonstilknytning: Universitetet i Stavanger, Nasjonalt senter for leseopplæring og leseforskning, Professor Olav Hanssens vei 10, 4021 Stavanger E-post: anne.haland@uis.no

\section{Referanser}

Alexander, R. (2006). Towards Dialogic Teaching: Rethinking Classroom talk (Third edition). Cambridge: Dialogs.

Alexander, R. (2008). Culture, Dialogue and Learning: Notes on an Emerging Pedagogy. I N. Mercer \& S. Hodginson (red.), Exploring Talk in School (s. 91-114). London: SAGE Publications Ltd.

Bakhtin, M. (1998 [1979]). Spørsmålet om talegenrane. Omsett og med etterord av R. Slaatelid. Bergen: Ariadne Forlag.

Barnes, D. (1992 [1976]). From Communication to Curriculum (Andre opplag). Portsmouth, NH: Boyton/ Cook-Heineman

Barnes, D. (2008). Exploratory Talk for Learning. I N. Mercer \& S. Hodgkinson (red.), Exploring Talk in School (s. 1-15) London: SAGE Publications Ltd.

Bernstein, B. (1971). Class, codes and control I. Theoretical Studies towards a Sociology of language. London: Routledge \& Kegan Paul. 
Bernstein, B. (1973). Class, codes and control II. Applied Studies towards a Sociology of Language. London: Routledge \& Kegan Paul.

Bernstein, B. (1975). Class, codes and control III. Towards a Theory of Educational Transmissions. London: Routledge \& Kegan Paul.

Bernstein, B. (1990). Class, codes and control IV. The Structuring of Pedagogic Discourse. London: Routledge \& Kegan Paul.

Callaghan, M., Knapp, P. \& Noble, G. (1993). Genre in Practice. I B. Cope \& M. Kalantzis (red.), The Power of Literacy: A Genre Approach to Teaching Writing (s. 179-202). London: University of Pittsburgh.

Callaghan, M. \& Rothery, J. (1988). Teaching Factual Writing. A Genre-Based Approach. The Report of the DSP Literacy Project Metropolitan East Region. Erskineville: Department of School Education.

Cazden, C. B. (1988). Classroom discourse: the language of teaching and learning. Portsmouth, NH: Heinemann.

Cope, B. \& Kalantzis, M. (1993). The Powers of literacy. Pittsburgh, Pa.: University of Pittsburgh Press.

Gee, J. P. (2003). Opportunity to Learn: a language-based perspective on assessment. Assessment in Education: Principles, Policy \& Practice, 10(1), 27-46.

Gibbons, P. (2009). Lyft språket. Lyft tänkande. Språk och lärande. Stockholm: Hallgren \& Fallgren.

Hammond, J., Burns, A., Joyce, H., Brosnan, D. \& Gerot, L. (1992). English for Social Purposes. A handbook for teachers of adult literacy. Sydney: National Centre for English Language Teaching and Research.

Hammond, J. \& Gibbons, P. (2001). What is scaffolding? I J. Hammond (red.), Scaffolding: a focus on teaching and learning in literacy education (s. 1-15). Newtown: Primary English Teaching Association.

Hedeboe, B. \& Polias, J. (2008). Genrebyrån. En språkpedagogisk funktionell grammatikk $i$ kontext. Stockholm: Hallgren \& Fallgren.

Hillocks, G. (1986). Research on written composition: new directions for teaching. Urbana, Ill.: ERIC Clearinghouse on Reading and Communication Skills.

Hoem, T., Håland, A. \& Skartveit, B. (2015). Kva vil det seie å vere leselærar på faget sine eigne premissar? Norsklceraren, 2, 61-72.

Håland, A. (2013). Bruk av modelltekstar i sakprega skriving på mellomtrinnet. Ei undersøking av korleis modelltekstar set spor i elevtekstar og korleis elevar posisjonerer seg i ulike sakprega skrivesituasjonar. Doktorgradsavhandling ved UiS nr. 210. Det humanistiske fakultetet, Nasjonalt senter for leseopplæring og leseforsking, Universitetet i Stavanger.

Kress, G. (1993). Genre as Social Process. I B. Cope \& M. Kalantzis (red.), The Power of Literacy. Pittsburg: University of Pittsburg Press.

Kress, G. (2003). Literacy in the new media age. London: Routledge.

Kristeva, J. \& Moi, T. (1986). The Kristeva reader. New York: Columbia University Press.

Kunnskapsdepartementet (2006). Lœreplanverket for Kunnskapsløftet (LK06). Læreplaner for gjennomgående fag i grunnskolen og videregående opplæring. Oslo: Kunnskapsdepartementet, Utdanningsdirektoratet.

Lancia, P. J. (1997). Literary borrowing: The effects of literature on children's writing. Reading Teacher, 50(6), 470-475.

Luke, A. (1994). The Social Construction of Literacy in the Primary School. Melbourne: Macmillan Education Australia.

Maagerø, E. (2015). Den strenge samtalen. Tekstsamtalen i sjangerpedagogikken. I H. Christensen \& R. S. Stokke (red.), Samtalens didaktiske muligheter (s. 33-51). Oslo: Gyldendal. 
Macken-Horarik, M. (1998). Exploring the requirements of critical school literacy. I F. Christie \& R. Misson (red.), Literacy and schooling (s. 74-103). London: Routledge.

Martin, J. (1998). Livet som substantiv: en undersøkelse av naturvitenskapens og humanioras univers. I K. L. Berge, P. Coppock \& E. Maagerø (red.), Å skape mening med språk: en samling artikler (s. 333-386). Oslo: Cappelen Akademisk Forlag, Landslaget for norskundervisning (LNU).

Martin, J. \& Rothery, J. (1980). Working papers in linguistics (Vol. 1). Sydney: Linguistic Department, University of Sydney.

Martin, J. \& Rothery, J. (1981). Working papers in linguistics (Vol. 2). Sydney: Linguistic Department, University of Sydney.

Mercer, N. \& Dawes, L. (2014). The study of talk between teachers and students, from the 1970s until the 2010s. Oxford Review of Education, 40(4), 430-445.

Mortimer, E. F. \& Scott, P. H. (2003). Meaning making in secondary science classrooms. Maidenhead: Open University Press.

Nystrand, M. (1997). Tekst på deling. Leseres innvirkning på unge skrivere. I T. L. Hoel \& L. S. Evensen (red.), Skriveteorier og skolepraksis (s. 130-152). Bergen: Fagbokforlaget.

Osland, E. (2005). Skarpe tenner. Bergen: Mangschou.

Rose, D. \& Martin, J. R. (2013). Skriva, Läsa, Lära. Genre, kunskap och pedagogik. Stockholm: Hallgren \& Fallgren.

Rothery, J. (1994). Exploring Literacy in School English. Sydney: Metropolian East Disadvantaged Schools program.

Ryvarden, L. (2000). Insekter. Norsk naturleksikon for barn. Oslo: DAMM \& SØN AS.

Scott, P. H. \& Asoko, H. (2006). Talk in science classrooms. I V. Wood-Robinson (red.), ASE Guide to Secondary Science education (s.157-165). Hatfield, UK: Association for Science Education (ASE).

Shanahan, T. \& Shanahan, C. (2008). Teaching Diciplinary Literacy to Adolenscents: Rethinking Content-Area Literacy. Harvard Educational Review, 78(1), 40-59.

Skrivesenteret: http://www.skrivesenteret.no/ressurser/sirkelen-for-undervisning-og-laering/

Stolarek, E. A. (1994). Prose Modeling and Metacognition: The Effect of Modeling on Developing a Metacognitive Stance toward Writing. Research in the Teaching of English, 28(2), 154-174.

Vygotskij, L. S. \& Cole, M. (1978). Mind in society: the development of higher psychological processes. Cambridge, Mass.: Harvard University Press.

Wood, D., Bruner, J. S. \& Ross, G. (1976). The Role of tutoring in Problem solving. Journal of child Psychology and Psychiatry, 17, 89-100.

\footnotetext{
${ }^{1}$ Elevene skal lage ei bok. Med «fagside» mener nok læreren et oppslag i denne boka.
} 